\title{
Follicle selection in domestic ruminants
}

\author{
J. E. Fortune, J. Sirois, A. M. Turzillo and M. Lavoir* \\ Department and Section of Physiology. College of Veterinary Medicine, Cornell University, Ithaca, \\ New York 14853, USA
}

\begin{abstract}
Summary. Ultrasound imaging has shown that cattle exhibit 2 or 3 waves of follicular development during an oestrous cycle. The waves consist of the contemporaneous appearance, about every 7 days, of a group of follicles $\geq 5 \mathrm{~mm}$ in diameter. One follicle gradually becomes larger than the rest (i.e. dominant). There are several lines of evidence suggesting that the waves occur regularly under conditions of basal LH and FSH. (1) Cycles with 3 waves of follicular development are longer and have longer luteal phases than do cycles with 2 waves, indicating that the number of waves in a cycle is determined by the time of luteal regression. (2) Cycles with 4 or 5 waves of follicular development can occur when the luteal phase is artificially prolonged with exogenous progesterone. (3) Waves of follicular development occur during pregnancy. However, the secondary surge of FSH may be important in initiating new follicular recruitment after ovulation, since suppression of the secondary surge delays the first wave of follicular development. Follicles are functionally dominant (capable of ovulating after luteal regression) while they are still growing and early during their plateau in growth. Functional dominance is lost some time between the early and late plateau phases, while the follicle is still morphologically dominant (i.e. the largest follicle). The factors that lead to dominance of one follicle and the mechanisms that suppress the growth of subordinate follicles are not well understood. When the luteal phase is artificially extended with low doses of exogenous progesterone, the normal pattern of follicular development is altered and the ovulatory follicle grows for a prolonged period of time. This finding indicates that subtle changes in the hormonal milieu can dramatically alter follicular dynamics and that the experimental model of prolonged dominance may be useful in studying the mechanisms of follicular dominance.

In contrast, patterns of follicular development in sheep must be assessed in more indirect ways, but sheep offer the advantage of breeds that differ in ovulation rate. Correlation of the endocrine environment with ovulation rate in this species provides a valuable approach to understanding the mechanisms controlling follicle selection and ovulation rate. It has been suggested that in some species a high ovulation rate is achieved by increased recruitment, whereas in others there is increased selection. There is evidence that oestradiol is involved in regulating the number of dominant follicles in sheep.

Follicular recruitment requires the presence of gonadotrophins, particularly FSH. In general, the mechanisms that regulate follicular selection and dominance in domestic ruminants are not well understood. Further experiments may determine the relative roles of paracrine factors and ovarian-pituitary-hypothalamic interactions in regulation of follicular selection and dominance in cattle and sheep.
\end{abstract}

Keywords: cattle; sheep; follicle; selection

*Present address: Department of Biomedical Science, University of Guelph, Guelph, Ontario, Canada NIG 2W1. 


\section{Introduction}

In general two processes lead to the development of the normal, species-specific number of ovulatory follicles. First, follicle recruitment results in the development of a pool or cohort of follicles from which the preovulatory follicle(s) is drawn and then, as a result of follicle selection, one follicle (or more, depending on the species or breed) becomes dominant and continues development towards ovulation, while the others regress. Understanding the processes of recruitment and selection and the phenomenon of dominance are of considerable practical importance. It is these processes that must be subverted or modulated to superovulate domestic animals or humans.

The approaches used for elucidating mechanisms of follicular selection have differed in cattle and sheep. In cattle, ultrasound imaging allows tracking of individual follicles as they grow and/or regress over time and patterns of follicular development can thus be determined with relative precision. In contrast, patterns of follicular development in sheep have been assessed in more indirect ways, although sheep offer the advantage of breeds that differ in ovulation rate. Correlation of the endocrine environment with ovulation rate in this species provides a valuable approach to understanding the mechanisms controlling follicle selection and ovulation rate.

\section{Follicular dynamics in cattle}

Patterns of follicular development have been carefully characterized in rodents (e.g. see review by Richards, 1980), but it has been more difficult to follow the dynamics of follicle development and regression in cattle and sheep. It is not clear how long it takes a follicle to grow from the resting stage to preovulatory status in the cow, but the process takes about 6 months in sheep (Cahill, 1981). Antrum formation occurs when bovine follicles are about $0.5 \mathrm{~mm}$ in diameter (Marion et al., 1968). Some researchers had suggested that the growth and regression of large follicles in cattle occur in waves (Rajakoski, 1960; Swanson et al., 1972; Ireland \& Roche, 1983). whereas others proposed that follicular growth is continuous and independent of stage of the oestrous cycle (Choudary et al., 1968; Donaldson \& Hansel, 1968: Marion \& Gier, 1971). In either case though, it seems clear that large follicles develop (and regress) during the luteal phase in cattle, in contrast to observations in primates (see Hodgen et al., 1985, for review). If all follicles $>5 \mathrm{~mm}$ are destroyed on Day 18 of the bovine cycle, oestrus still occurs around the expected time (Matton et al., 1981), indicating that follicles can grow from $<5 \mathrm{~mm}$ to ovulatory size $(1-2 \mathrm{~cm})$ fairly rapidly.

Until recently the techniques used in studying patterns of follicular development in cattle involved measurement, counting, and histological evaluation of ovaries of animals killed at various times during the oestrous cycle or marking of follicles with ink, followed by serial laparoscopy. These techniques generated much useful information on the development and regression of large follicles in cattle, but they clearly have limitations. In contrast, the development of ultrasonic probes that can be used intrarectally to visualize bovine ovaries opened new possibilities for examining the dynamics of follicular growth and regression in cattle. Pierson \& Ginther (1984) first used ultrasound imaging to count the numbers of follicles of various sizes in bovine ovaries throughout the cycle. On the basis of such counts, they suggested that 2 follicles of ovulatory size develop during the oestrous cycle, one during dioestrus and the other during the preovulatory period (Pierson \& Ginther, 1987). In addition they provided evidence suggesting that the ovulatory follicle is selected (i.e. becomes dominant) 3-4 days before ovulation (Pierson \& Ginther, 1988).

We used ultrasound imaging to follow the growth and regression of individual follicles in bovine ovaries (Quirk et al., 1986) and found that individual follicles with antral diameters $\geq 5 \mathrm{~mm}$ can be followed with certainty by videotaping each ultrasound examination and reviewing the tapes sequentially. Our results indicated that, in cattle, there is variability amongst heifers in the size of the ovulatory follicle at various times before oestrus, that size alone is not a reliable predictor of the 
ovulatory follicle until the day of oestrus, and that other large follicles regress as the ovulatory follicle enlarges during the follicular phase (Quirk et al., 1986).

More recently ultrasonography has been used to follow the development of individual follicles $\geq 5 \mathrm{~mm}$ in diameter during complete oestrous cycles (Fig. 1). We found that follicular development occurs in waves, with each wave consisting of the contemporaneous appearance of 3-6 follicles $\geq 5 \mathrm{~mm}$ in diameter (Fortune et al., 1988; Sirois \& Fortune, 1988). Several days after the emergence of a wave, one follicle has become larger than the rest; it continues to grow while the smaller follicles in the cohort regress. In our herd most heifers exhibit 3 successive waves of follicular development during an oestrous cycle, beginning on average on Days 2, 9 and 16, with ovulation of the dominant follicle of the third wave, In an alternative pattern, in about $25 \%$ of our heifers, there are 2 waves of development with ovulation of the dominant follicle of the second wave. Savio et al. (1988) also reported the emergence of 3 dominant follicles during most cycles, but Knopf et al. (1989) found a predominant pattern of 2 waves of follicular development and an alternative pattern of 3 waves in their herd. The finding that follicular development in cattle occurs in waves is exciting, since it may help to explain the variability observed when cattle are superovulated and because it offers new opportunities for studying the regulation of ovarian follicular development.

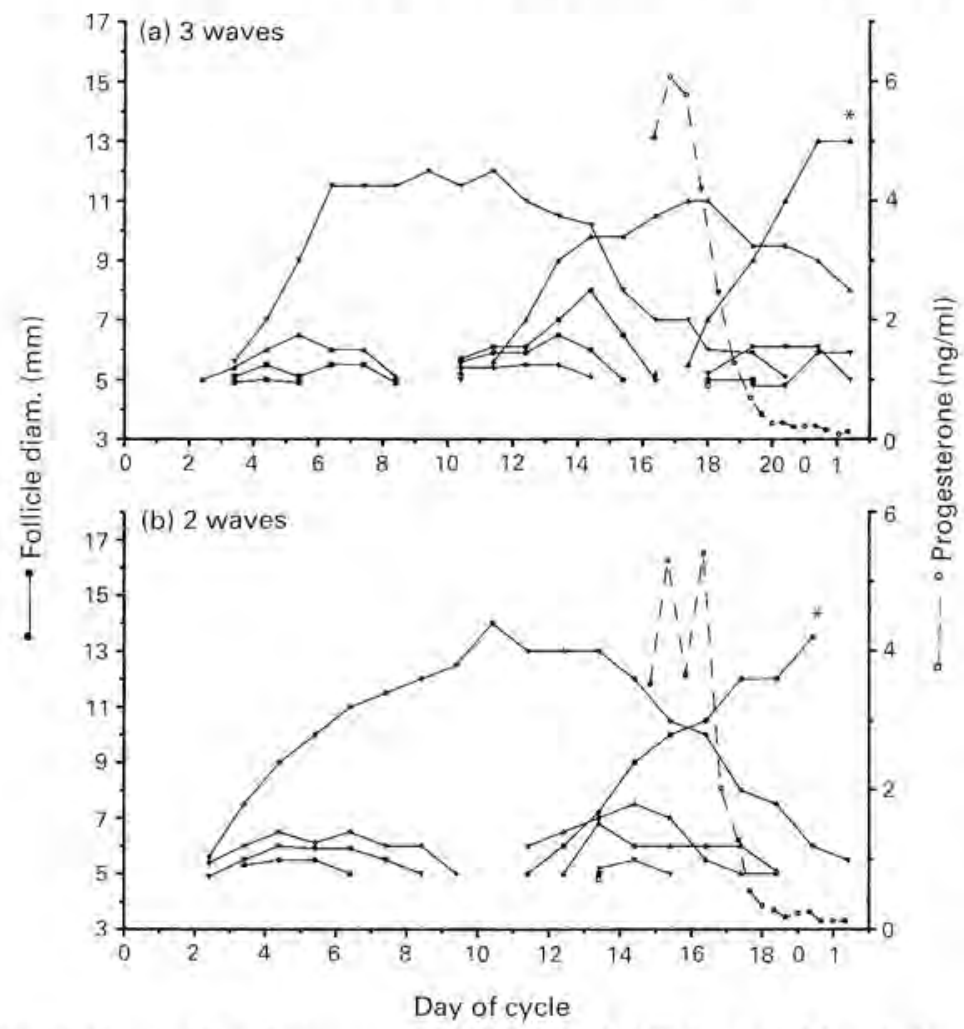

Fig. 1. Patterns of growth and regression of individual follicles (solid lines) during complete oestrous cycles with 3 (a) and 2 (b) waves of follicular development. The asterisk indicates the last day on which the ovulatory follicle was observed and the broken line shows progesterone concentrations.

\section{Morphological versus functional dominance}

Since dominant follicles appear to suppress the development of subordinate follicles, at least part of the variability in the response to superovulatory treatments may be due to the presence or 
absence of a dominant follicle at the beginning of the superovulatory regimen. Because the presence of a dominant follicle may diminish the response to superovulatory treatments (Pierson \& Ginther. 1988; Grasso et al., 1989), it is important to know when functionally dominant follicles are present. Since analysis of follicular dynamics shows that dominant non-ovulatory follicles remain as the largest follicle for several days after the start of the succeeding wave, it seemed possible that a dominant follicle retains morphological dominance (largest follicle on a pair of ovaries) longer than it retains functional dominance (ability to suppress the growth of other follicles).

We used the first wave of follicular development to explore the relationship between morphological and functional dominance in non-ovulatory, dominant follicles (Lavoir \& Fortune, 1990). The first wave was chosen because it begins at a predictable time (Day 1-3), in the absence of a previous dominant follicle (which has just ovulated), and, in contrast to the second wave of follicular development, is never the ovulatory wave. The ability to ovulate in response to a luteolytic injection of prostaglandin (PG) F-2 $\alpha$ was used as the criterion for functional dominance. Luteolysis was induced in a total of 15 heifers at 3 times during the first wave of follicular development: (1) while the dominant follicle of the first wave was still growing, (2) early during its plateau in growth, or (3) late in its plateau in growth (Fig. 2). Growth and regression of individual follicles $\geq 5 \mathrm{~mm}$ were followed by daily ultrasonography. Of 5 heifers injected during the growing phase of the first dominant follicle, 4 ovulated that follicle. Of the 6 heifers injected during the early plateau phase, 4 ovulated the largest follicle and 2 ovulated a new follicle, which was already visible at the time of PGF-2 $\alpha$ injection. All 4 heifers injected during the late plateau phase failed to ovulate the largest follicle and ovulated a follicle recruited from the second wave of follicular development. Control heifers $(\mathrm{N}=3)$, injected with saline at similar stages of follicular development, had normal oestrous cycles with typical waves of follicular development.

The results suggest that, while the dominant follicle of the first wave is still actively growing, morphological dominance usually coincides with functional dominance. In contrast, by the late plateau phase this congruence between morphological and functional dominance has been lost. The early plateau phase appears to be a transitional period when the morphologically dominant follicle may or may not be functionally dominant. Since the largest follicle of the first wave may be functionally non-dominant while it remains morphologically dominant, size alone is not a good indicator of functional dominance. Therefore, assessment of the effects of a dominant follicle on ovarian responses should focus on analysis of the effects of functionally dominant follicles.

\section{Regulation of follicular waves in cattle}

It is clear that the development of medium-sized and large follicles in cattle occurs in waves. The regularity of the patterns allows experimental manipulations designed to determine how these patterns are controlled. The consistent pattern of follicular waves during the oestrous cycle led us to propose that, when the ovaries are exposed to basal concentrations of gonadotrophins, a follicular wave is produced about every 7 days. This regular succession of waves could explain why some heifers have 2 waves of follicular development, whereas most heifers in our herd exhibit 3 waves. That is, heifers with longer cycles, or cycles in which the 2 nd wave of follicular development begins several days later than average, would have 2, rather than 3, waves of follicular development, because at the time of luteal regression the dominant follicle of the 2 nd wave would still be healthy and capable of ovulating. We tested this hypothesis by comparing 2- and 3-wave cycles in a group of 16 heifers. Animals that exhibited 2 waves had significantly shorter cycles and luteal phases. In these heifers the dominant follicle of the first wave grew larger on average and this was associated with a later time of appearance of the second wave (Fortune \& Sirois, 1989). These results are consistent with the observations of Ginther et al. (1989a), who also found that the luteal phase was significantly shorter in heifers with 2 waves of follicular development.

To test experimentally the idea that the number of waves per cycle is at least partly determined by the length of the cycle, we artificially extended the luteal phase of the cycle with progesterone- 


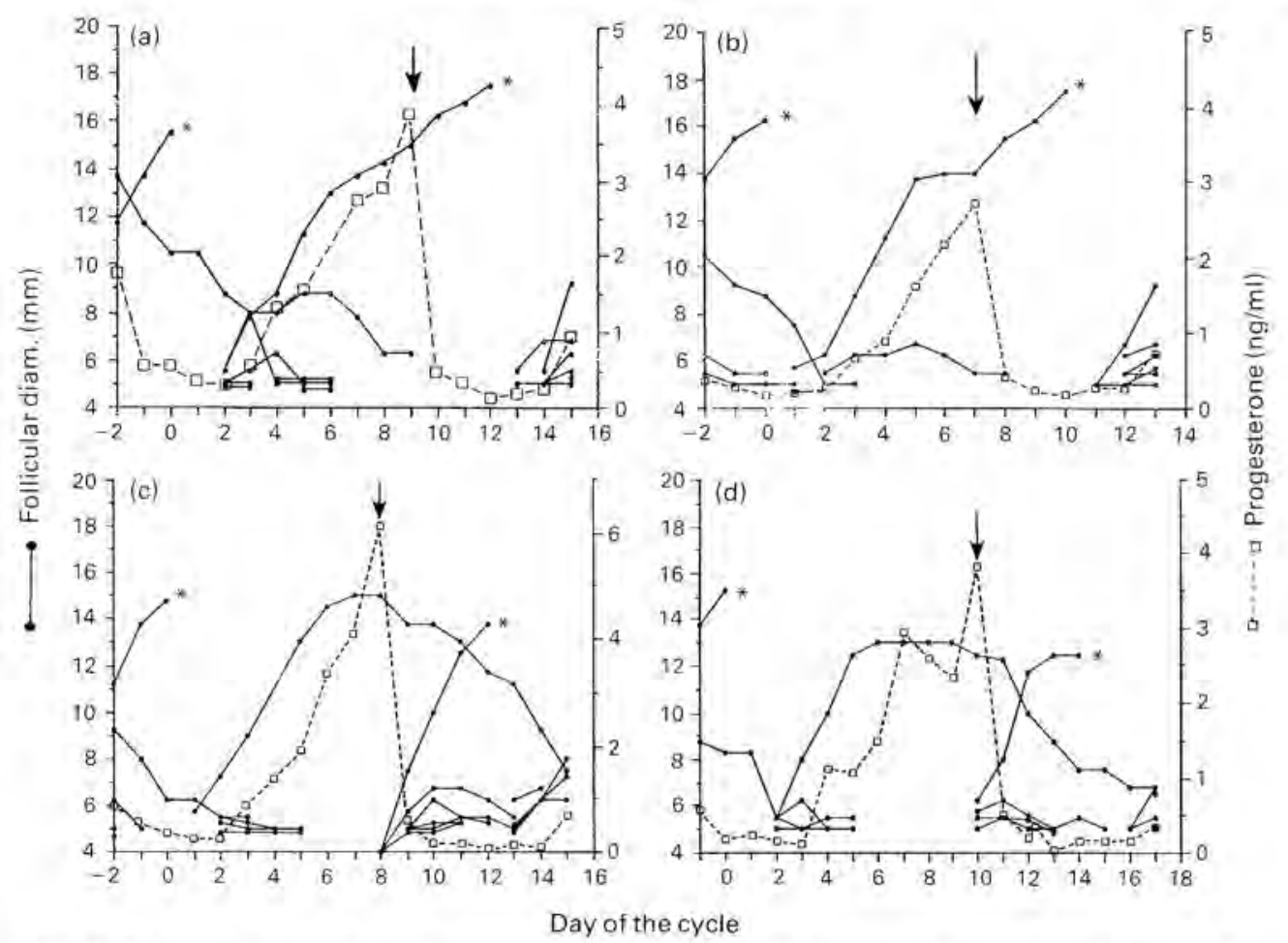

Fig. 2. Patterns of growth and regression of individual follicles (solid lines) after injection of a luteolytic dose of PGF- $2 \alpha$ during the growing phase (a), early plateau phase (b,c), or late plateau phase (d) of the dominant follicle of the first wave of follicular development. The asterisk indicates the last day on which the ovulatory follicle was observed and the broken line shows progesterone concentrations.

releasing devices (CIDRs) placed intravaginally for 14 days beginning on Day 14 of the cycle (Sirois \& Fortune, 1989). Treating the animals with 2 CIDRs that were changed at regular intervals maintained progesterone at normal luteal levels. Of the 6 animals treated, 3 exhibited regular waves under these conditions, having 4 or 5 waves during their 30-day 'cycle' (Fig. 3c). However, in the other 3 animals, and in 6 animals in which treatment with 1 CIDR maintained progesterone at subluteal levels (about $1.5 \mathrm{ng} / \mathrm{ml}$ ) for a prolonged period, only 2 or 3 waves of follicular development occurred during the 30-day cycle (Fig. 3b). In these animals the final wave of follicular development was considerably prolonged, the dominant follicle grew larger than normal, and the development of other follicles was completely suppressed for a prolonged period of time. These experiments indicate that, although additional waves of follicular development can occur if the luteal phase is prolonged, subtle changes in endocrine milieu can dramatically change the timing of follicular waves and prolong the period of dominance. The phenomenon of prolonged dominance provides direct evidence suggesting that the dominant follicle regulates the appearance of the succeeding wave. In addition, experimentally prolonged dominance provides a very useful model for studying follicular dominance in cattle.

Additional evidence for the regularity of waves under conditions of basal LH and FSH comes from the observation of Ginther et al. (1989b) that regular follicular waves continue during pregnancy. Taken together, these results suggest that in cattle waves of follicular development occur regularly during the oestrous cycle and pregnancy, when LH and FSH are at basal concentrations. The gonadotrophin surges perturb the pattern of regular waves by triggering ovulation of the follicle that is functionally dominant at the time of oestrus. However, an additional, secondary 

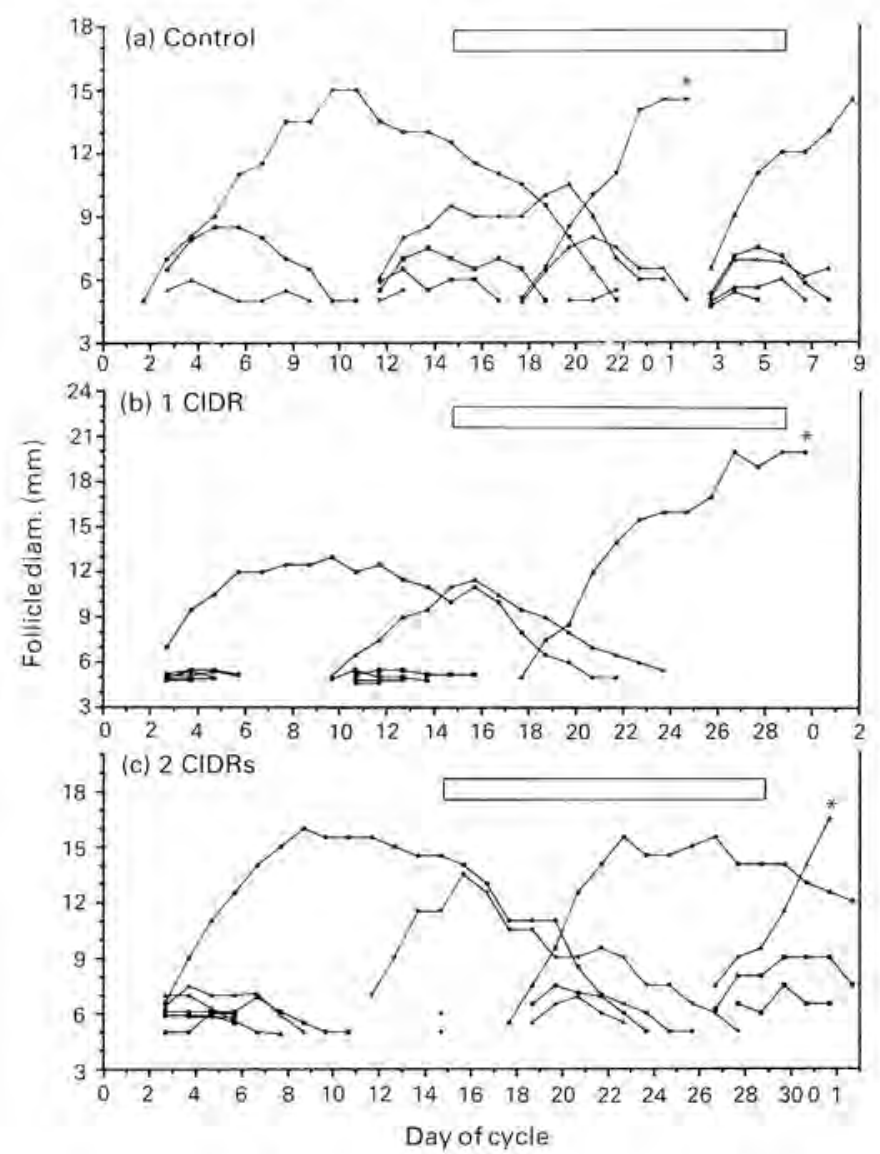

Fig. 3. Representative patterns of ovarian follicular development during a normal oestrous cycle (a), a cycle artificially lengthened with low levels of progesterone (b) and an oestrous cycle lengthened with high levels of exogenous progesterone (c). The open rectangle indicates the interval of treatment with an intravaginal progesterone-releasing device (CIDR) or a blank device (control; for details see text).

surge of FSH occurs about 1 day after the $\mathrm{LH} / \mathrm{FSH}$ surge. Experiments with rats provided evidence for a role for a similar secondary surge of FSH in the development of follicles for the next ovulation (Grady et al., 1982). We explored the relationship of the secondary surge of FSH to follicular development in cattle by suppressing the surge with injections of steroid-free, bovine follicular fluid (bFF, containing inhibin; Turzillo \& Fortune, 1990). Five injections of bFF, given every $12 \mathrm{~h}$ beginning $12 \mathrm{~h}$ after the onset of oestrus, completely suppressed the secondary surge (Fig. 4), without affecting LH concentrations, in $6 / 6$ heifers. Control heifers $(\mathrm{N}=5)$ injected with saline exhibited the secondary surge at the expected time. Daily ultrasonographic examinations revealed that the appearance of the first wave of follicular development was delayed in bFF-treated heifers (Day $3.3 \pm 0.3$ compared with Day $1.4 \pm 0 \cdot 2, P<0.0001 ;$ Fig. 5 ). This was accompanied by a concomitant delay in the early luteal increase in plasma oestradiol (peak concentrations on Day $6 \cdot 3 \pm 0 \cdot 6$ compared with Day $4.2 \pm 0.2 ; P<0.05$ ). The 2 nd wave of follicular development was also delayed in treated heifers (Day 12.7 \pm 0.4 compared with Day $10 \cdot 4 \pm 0 \cdot 6, P<0 \cdot 01$ ). Of 6 bFF-treated heifers, 5 had 2 waves of follicular development, whereas $4 / 5$ control heifers had 3 waves of follicular development. Concentrations of $\mathrm{LH}$ and progesterone and cycle length were not affected by bFF treatment. Taken together, these results suggest that the delay in the 1st wave of follicular 
development led to a delay in the 2 nd wave, which resulted in the presence of a healthy dominant follicle of the 2nd wave at the time of luteolysis in most treated heifers and subsequent ovulation of that follicle. Although a direct effect of some component(s) of bFF on ovarian follicles cannot be ruled out, delayed follicular growth associated with suppression of the secondary FSH surge suggests that this surge is important in the re-initiation of follicular development after ovulation.

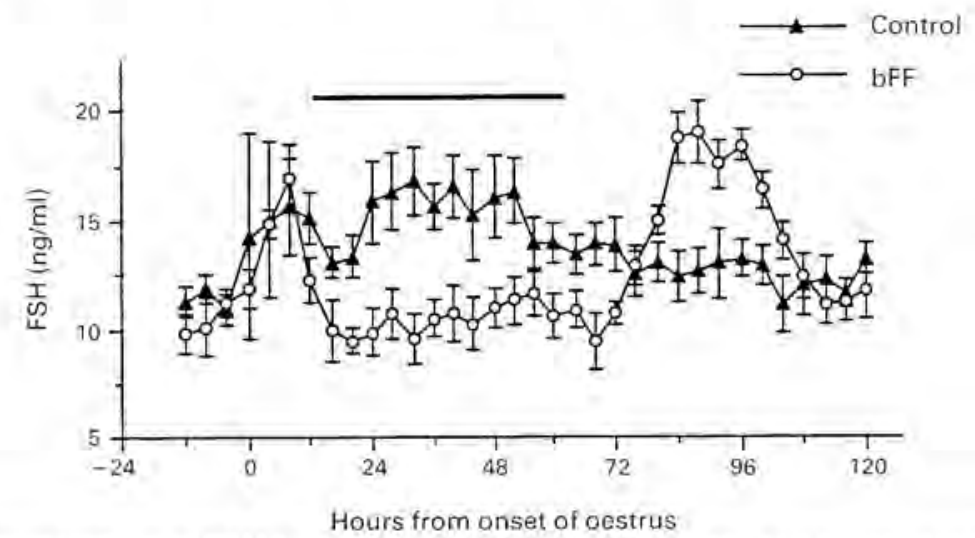

Fig. 4. Concentrations of FSH (mean \pm s.e.m.) in plasma collected at 4-h intervals from heifers injected with $10 \mathrm{ml}$ bovine follicular fluid (bFF) or $10 \mathrm{ml}$ saline (control) every $12 \mathrm{~h}$ during the injection period indicated by the horizontal bar.

(a) Heifer 443 (control)

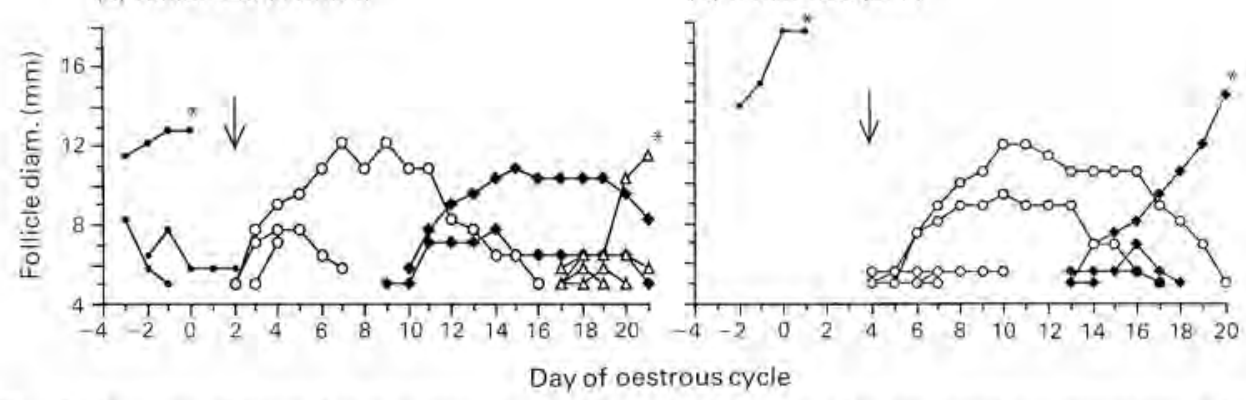

Fig. 5. Patterns of growth and regression of individual follicles during complete oestrous cycles in 2 representative heffers: (a) control, (b) treated with bovine follicular fluid (bFF). Arrows indicate day of appearance of dominant follicles of the first wave of follicular development. Asterisks denote ovulatory follicles. Symbols denote follicles from the previous cycle ( - and follicles in the first $(-\mathrm{O}-)$, second $(-\rightarrow)$, and third $(-\Delta-)$ waves.

\section{Follicular recruitment and selection in sheep}

Insight into the patterns and regulation of ovine follicular development has been gained by comparison of follicle populations in hypophysectomized and intact ewes and by serial laparoscopy following dye marking of individual follicles. It has been estimated that follicular development takes 6 months, with 2-3 follicles leaving the pool of resting follicles to begin growth each day (Turnbull et al., 1977; Cahill \& Mauléon, 1980). Driancourt \& Fry (1988) have divided folliculogenesis in sheep into two stages-basal and tonic. Basal folliculogenesis includes development up to 
$2 \mathrm{~mm}$ in diameter and is apparently not dependent on gonadotrophins, since hypophysectomized sheep exhibit follicular development up to this stage (Dufour et al., 1979; Driancourt et al., 1987). Tonic folliculogenesis includes growth from $2 \mathrm{~mm}$ to preovulatory size and is gonadotrophindependent, Recruited follicles are $>2 \mathrm{~mm}$ in diameter and selection occurs from among the pool of follicles of this size. All follicles that can be clearly identified as 'selected' are $>4 \mathrm{~mm}$ in diameter. Therefore, to be recruited and selected a follicle must have entered the gonadotrophin-dependent phase of development. Granulosa cells from follicles $>4 \mathrm{~mm}$ have acquired LH receptors (Carson et al., 1979) and exhibit maximal responses to FSH in terms of cAMP and oestradiol production (Tsonis et al., 1984b; Henderson et al., 1985; McNatty et al., 1986). When some follicles $>2 \mathrm{~mm}$ in diameter were cauterized ovulation still occurred at the normal time, as long as some follicles $>2 \mathrm{~mm}$ remained in the ovaries. However, destruction of all follicles with diameters $>2 \mathrm{~mm}$ significantly delayed ovulation (Tsonis et al., 1984a).

In contrast to cattle, in which multiple ovulations are rare, sheep offer the advantage of breeds that vary in prolificacy. This affords the opportunity to explore various potential mechanisms for control of ovulation rate by comparing various characteristics in breeds differing in natural prolificacy. One approach has been characterization of the numbers of follicles at different stages of development at various times relative to ovulation in breeds differing in ovulation rate. In some experiments follicles have been marked with dye and followed by serial laparoscopy. Driancourt et al. (1986) have determined that different prolific breeds achieve a high ovulation rate by different mechanisms (Fig. 6). Romanov ewes recruit a larger number of follicles $(6.6 \pm 1.4$ vs $2.8 \pm 1.4$ in lle-de-France ewes), whereas Finns recruit about the same number of follicles as non-prolific breeds, but a greater percentage are selected for ovulation. In contrast Booroola ewes appear to achieve prolificacy through continuous recruitment during the follicular phase coupled with a higher rate of selection. Driancourt et al. (1990b) have also examined lines of Finn and Merino sheep that differ in prolificacy. There was a lower proportion of atresia in follicles $>3 \mathrm{~mm}$ in diameter in Merinos selected for higher prolificacy compared with control Merinos. Finn ewes with high ovulation rates recruited more follicles than did Finn ewes with lower ovulation rates. In addition, the response of different breeds to hCG-induced ovulation during the prepubertal period, anoestrus, and the luteal phase was similar to the adult ovulation rate, indicating that the mechanisms that promote prolificacy operate at stages other than the follicular phase of the cycle (Driancourt et al., 1990a).

A second approach to understanding the mechanisms of prolificacy has been to examine the characteristics of selected follicles in different breeds. The only features that prolific breeds appear to have in common are a reduced diameter of ovulatory follicles and unaltered growth rates (Driancourt \& Fry, 1988). Brown \& Driancourt (1989) have suggested that differences in capillary blood flow may be related to the smaller size of ovulatory follicles in breeds with high fecundity. They found that capillary blood flow per unit volume of theca was greatest in $3 \cdot 1-5 \cdot 0-\mathrm{mm}$ follicles in prolific Romanov ewes, whereas blood flow was maximum in larger follicles $(5 \cdot 1-7 \mathrm{~mm})$ in the non-prolific Prealpes-du-Sud breed. Webb et al. (1989) analysed follicular populations in 3 breeds differing in ovulation rate from the day before until 2 days after injection of a luteolytic dose of PGF-2 $\alpha$. They found that follicles that produced low amounts of oestradiol in vitro (oestrogeninactive follicles) had lower numbers of granulosa cells. Although oestradiol production by oestrogen-active follicles was similar in all 3 breeds, granulosa cell number was significantly lower in follicles from the prolific Finnish Landrace ewes than in two less prolific breeds. Therefore, granulosa cell number and oestrogen production differed in atretic (non-selected) follicles, but differences in these measures do not explain differences in numbers of selected follicles among breeds differing in ovulation rate.

A third approach has been analysis of the endocrine environments in breeds differing in fecundity. Cahill et al. (1981) analysed concentrations of LH, FSH, prolactin, oestradiol and progesterone in prolific Romanov and non-prolific Ile-de-France ewes. Progesterone concentrations during the luteal phase were highly correlated with the number of preovulatory follicles, but the 

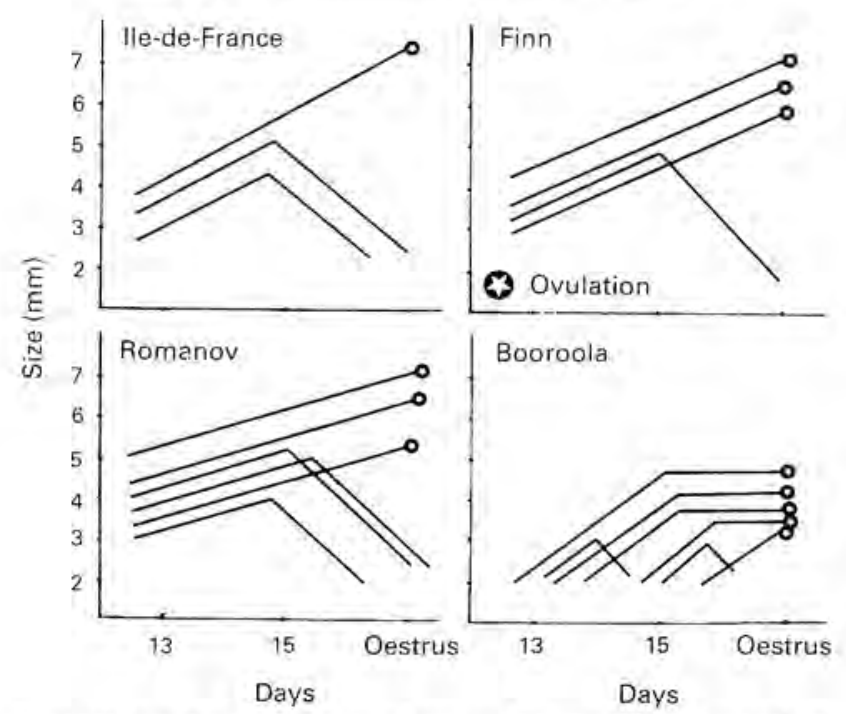

Fig. 6. Schematic representation of preovulatory enlargement in control (Hle-de-France) and prolific (Romanov, Finn, Booroola) ewes. Taken from Driancourt et al. (1986).

concentrations of $\mathrm{LH}$, oestradiol and prolactin did not differ between breeds. In contrast, the secondary FSH surge was significantly larger in Romanov ewes and the area under the peak was correlated with the number of antral follicles present during the succeeding follicular phase. Analysis of the binding of FSH to granulosa cells from Booroola ewes that were homozygous, heterozygous or non-carriers of the F gene (which influences ovulation rate), showed no differences among the 3 groups (McNatty et al., 1989). Therefore, differences in binding of FSH do not appear to be responsible for the earlier maturation of follicles in FF or F+ ewes.

\section{Mechanisms of follicular selection}

Development of antral follicles up to the stage of recruitment appears not to depend on gonadotrophins, since it can proceed in the absence of the pituitary (see above). However, studies with sheep indicate that recruitment requires at least basal levels of gonadotrophins (Driancourt et al., 1987). There is evidence suggesting that in cattle the secondary surge of FSH may play a role in initiating follicular recruitment following ovulation (Turzillo \& Fortune, 1990). Driancourt \& Fry (1988) have concluded that both FSH priming and LH administration are necessary for follicular recruitment in anoestrous sheep. However, superovulation of cattle with preparations of pure FSH indicates that basal levels of $\mathrm{LH}$ are sufficient to support recruitment and selection of additional follicles in that species. These results provide evidence for a critical role for FSH in regulation of the number of follicles selected for dominance and ovulation. However, Baird et al. (1985) found that doubling plasma FSH concentrations by FSH infusion increased ovulation rate in only $30 \%$ of treated sheep. There is not a clear relationship between plasma FSH concentrations and ovulation rate in breeds differing in prolificacy (see Driancourt \& Fry, 1988, for review), but sensitivity to gonadotrophins and feedback mechanisms may also vary among these breeds. The dose and duration of treatment with exogenous FSH may be critical in determining effects of FSH concentrations on ovulation rate. Zeleznik (1989) has reported that in rhesus monkeys administration of low doses of FSH for a longer period was more effective in raising ovulation rate than were higher doses for shorter periods. In the future a careful analysis of the effects of alteration of gonadotrophin concentrations on follicular recruitment and selection could determine more clearly the relative roles of LH and FSH in follicular recruitment and selection in domestic ruminants, 
There is some evidence that dominant follicles may achieve and maintain dominance by feedback effects on gonadotrophin secretion. FSH declines during the follicular phase in cattle (e.g. Quirk \& Fortune, 1986) and sheep (Cahill et al., 1981) and it has been inferred that production of oestradiol and/or inhibin by the dominant follicle(s) is responsible for this decline, thereby depriving subordinate follicles of sufficient amounts of FSH for their further development. Ewes treated with oestradiol implants during the follicular phase had significantly reduced ovulation rates (Adams et al., 1989). In primates there is experimental evidence suggesting that higher concentrations of FSH are needed for follicular development in the early follicular phase than are necessary to support the dominant follicle later during the follicular phase (Zeleznik, 1989). However, if lack of FSH support is the primary factor involved in the regression of subordinate follicles, FSH should decline during the dominance phase of dominant, non-ovulatory follicles in cattle. There are no obvious depressions in FSH in bovine plasma except during the follicular phase, but careful analysis of plasma FSH in conjunction with ultrasonographic studies could determine whether subtle changes in FSH concentrations are associated with follicular dominance during non-ovulatory waves of follicular development.

It is not clear what role autocrine and paracrine (i.e. ovarian) factors play in follicular selection and dominance. Follicular fluid is known to contain substances that are inhibitory or stimulatory to follicular function in vitro. The extent to which the production of these substances by one follicle can influence development of follicles in the ipsilateral or contralateral ovary is not clear. It is possible that the balance of inhibitory and stimulatory factors within an individual follicle influences its ability to respond to changes in concentrations of endogenous gonadotrophins and in this way determines whether it is selected for further development.

We thank S. Vincent, T. Kimmich and J. Roycroft for excellent technical assistance; Dr M. M. Hinshelwood and Dr A. Voss for help during collection of blood samples; Dr K. L. MacMillan and the AHI Plastic Moulding Co. (New Zealand) for kindly providing CIDRs; and Dr D. J. Bolt, Dr G. D. Niswender, Dr L. E. Reichert, Jr and Dr W. Hansel for reagents used in the FSH, LH and progesterone radioimmunoassays. This research was supported by a grant from the USDA (86-CRCR-1-2125).

\section{References}

Adams, N.R., Atkinson, S. \& Sanders, M.R. (1989) Effects of oestradiol implants on the ovulation rate of the ewe. J. Reprod. Fert. 87, 169-174.

Baird, D.T., McNeilly, A.S., Wallace, J.M. \& Webb, R. (1985) Infusion of FSH increases ovulation rate in Welsh Mountain ewes. Proc. 5th Reinier de Graaf Symp., p, 13. Nijmegen.

Brown, B.W. \& Driancourt, M.A. (1989) Blood flow in the ovaries and ovarian follicles of Romanoy and Préalpes-du-Sud ewes. J. Reprod. Fert. 85, 317-323.

Cahill, L.P. (1981) Folliculogenesis in the sheep as influenced by breed, season and oestrous cycle. $J$. Reprod. Fert., Suppl. 30, 135-142.

Cahill, L.P. \& Mauléon, P. (1980) Influence of seasson. cycle and breed on follicular growth rates in sheep. J. Reprod. Fert. 58, 32I-328.

Cahill, L.P., Saumande, J., Ravault, J.P., Blanc, M., Thimonier, J., Mariana, J.C. \& Mauléon, P. (1981) Hormonal and follicular relationships in ewes of high and low ovulation rates. I. Reprod. Fert. 62, 141-150.

Carson, R.S., Findlay, J.K., Burger, H.G. \& Trounson, A.O. (1979) Gonadotropin receptors of the ovine ovarian follicle during follicular growth and atresia. Biol. Reprod. 21, 75-87.
Choudary, J.B., Gier, J.T. \& Marion, G.B. (1968) Cyclic changes in bovine vesicular follicles. J. Anim. Sci. 27, 468-471.

Donaldson, L.E. \& Hansel, W. (1968) Cystic corpora lutea and normal and cystic graafian follicles in the cow. Aust. vet. J. 44, 304-308.

Driancourt, M.A. \& Fry, R.C. (1988) Differentiation of ovulatory follicles in sheep. J. Anim. Sci. 66 (Suppl. 2), 9-20.

Driancourt, M.A., Gauld, I.K., Terqui, M. \& Webb, R. (1986) Variations in patterns of follicle development in prolific breeds of sheep. J. Reprod. Fert. 78, 565575.

Driancourt, M.A., Fry, R.C., Clarke, 1.J. \& Cahill, L.P. (1987) Follicular growth and regression during the \& days after hypophysectomy in sheep. I. Reprod. Ferl. 79, 635-641.

Driancourt, M.A., Bodin, L., Boomarov, O., Thimonier, J. \& Elsen, J.M. (1990a) Number of mature follicles ovulating after a challenge of human chorionic gonadotropin in different breeds of sheep at different physiological stages. J. Anim. Sci. 68, 719-724.

Driancourt, M.A., Castonguay, F, Bindon, B.M., Piper, L.R., Quirke, J.F. \& Hanrahan, J.P. (1990b) Ovarian 
follicular dynamics in lines of sheep (Finn, Merinos) selected on oyulation rate. J. Anim. Sci. 68, 2034 2041.

Dufour, J.J., Cahill, L.P. \& Mauléon, P. (1979) Shortand long-term effects of hypophysectomy and unilateral ovariectomy on ovarian follicular populations in sheep. J. Reprod. Fert. 57, 301-309.

Fortune, J.E. \& Sirois, J. (1989) The use of ultrasonography to study the regulation of follicular development in cattle and horses. In Follicular Development and the Ovulatory Response, pp, 11-20, Eds A. Tsafriri \& N. Dekel. Serono Symposia, Rome.

Fortune, J.E., Sirois, J. \& Quirk, S.M. (1988) The growth and differentiation of ovarian follicles during the bovine estrous cycle. Theriogenology 29, 95-110.

Ginther, O.J., Knopf, L. \& Kastelic, J.P. (1989a) Temporal associations among ovarian events in cattle during oestrous cycles with two and three follicular waves. J. Reprod. Fert. 87, 223-230.

Ginther, O.J., Knopf, L. \& Kastelic, J.P. (1989b) Ovarian follicular dynamics in heifers during early pregnancy. Biol. Reprod. 41, 247-254.

Grady, R.R., Charlesworth, M.C. \& Schwartz, N.B. (1982) Characterization of the FSH-suppressing activity in follicular fluid. Recent Prog. Horm. Res. 38, 409-447.

Grasso, F., Guilbault, L.A., Roy, G.L. \& Lussier, J.G. (1989) Ultrasonographic determination of ovarian follicular development in superovulated heifers pretreated with FSH-P at the beginning of the estrous cycle. Theriogenology 31, 1209-1220.

Henderson, K.M., Kieboom, L.E., MeNatty, K.P., Lun, S. \& Heath, D. (1985) Gonadotrophin stimulated cyclic AMP production by granulosa cells from Booroola by Romney ewes with and without a fecundity gene. J. Reprod. Fert. 75, 111-120.

Hodgen, G.D., Kenigsburg, D., Collins, R.L. \& Schenken, R.S. (1985) Selection of the dominant ovarian follicle and hormonal enhancement of the natural cycle. In In Vitro Fertilization and Embryo Transfer, Vol. 442, pp. 23-37. Eds M. Seppala \& R. G. Edwards. N.Y. Academy of Sciences.

Ireland, J.J. \& Roche, J.F. (1983) Development of nonovulatory antral follicles in heifers: changes in steroids in follicular fluid and receptors for gonadotropins. Endocrinology 112, 150-156.

Knopf, L., Kastelic, J.P., Schallenberger, E. \& Ginther, O.J. (1989) Ovarian follicular dynamics in heifers: test of two-wave hypothesis by ultrasonically monitoring individual follicles. Dom. Anim. Endocrinol. 6, $111-119$

Lavoir, M. \& Fortune, J.E. (1990) Follicular dynamics in heifers after injection of $\mathrm{PGF}_{20}$ during the first wave of follicular development. Theriogenology 33, 270 , abstr.

Marion, G.B. \& Gier, H.T. (1971) Ovarian and uterine embryogenesis and morphology of the non-pregnant female mammal. J. Anim. Sci. 32 (Suppl. 1), 24-47.

Marion, G.B., Gier, H.T. \& Choudary, J.B. (1968) Micromorphology of the bovine ovarian follicular system. J. Anim. Sci. 27, 451-465,

Matton, P., Adelakoun, V., Couture, Y. \& Dufour, J.J. (1981) Growth and replacement of the bovine ovarian follicles during the estrous cycle. J. Anim. Sci, 52,813820 .
McNatty, K.P., Lun, S., Heath, D.A., Ball, K., Smith, P., Hudson, N.L., MeDiarmid, J., Gibb, M. \& Henderson, K.M. (1986) Ovarian activity in Booroola by Merino ewes which were homozygous, heterozygous and non carriers of a major gene influencing their ovulation rate. J. Reprod. Ferı. 77, 193-205.

McNatty, K.P., Lun, S., Heath, D.A., Hudson, N.L., O'Keeffe, L.E. \& Henderson, K.M. (1989) Binding characteristics of ${ }^{125}$ I-labelled human FSH to granulosa cells from Booroola ewes which were homozygous, heterozygous or non-carriers of a major gene(s) influencing their ovulation rate. J. Reprod. Fert. 86, 27-38.

Pierson, R. \& Ginther, O.J. (1984) Ultrasonography of the bovine ovary. Theriogenology 21, 495-504.

Pierson, R.A. \& Ginther, O.J. (1987) Follicular populations during the estrous cycle in heifers. I. Influence of day. Anim. Reprod. Sci. 14, 165-176.

Pierson, R.A. \& Ginther, O.J. (1988) Follicular populations during the estrous cycle in heifers. III. Time of selection of the ovulatory follicle. Anim. Reprod. Sci. $16,81-95$.

Quirk, S.M. \& Fortune, J.E. (1986) Plasma concentrations of gonadotrophins, preovulatory follicular development and luteal function associated with bovine follicular fluid-induced delay of oestrus in heifers. $J_{+}$Reprod, Fert. 76, 609-621.

Quirk, S.M., Hickey, G.J. \& Fortune, J.E. (1986) Growth and regression of ovarian follicles during the follicular phase of the oestrous cycle in heifers undergoing spontaneous and PGF-2a-induced luteolysis. $J$. Reprod. Fert. 77, 211-219.

Rajakoski, E. (1960) The ovarian follicular system in sexually mature heifers with special reference to seasonal, cyclical and left-right variations. Acta endocr., Copenh., Suppi. 52, 7-68.

Richards, J.S. (1980) Maturation of ovarian follicles: actions and interactions of pituitary and ovarian hormones on follicular cell differentiation. Physiol. Rev. $60,51-89$.

Savio, J.D., Keenan, L., Boland, M.P. \& Roche, J.F. (1988) Pattern of growth of dominant follicles during the oestrous cycle of heifers. J. Reprod. Fert. 83, 663671.

Sirois, J. \& Fortune, J.E. (1988) Follicular dynamics during the estrous cycle in heifers monitored by realtime ultrasonography. Biol Reprod. 39, 308-317.

Sirois, J. \& Fortune, J.E. (1989) Lengthening the bovine estrous cycle with low levels of progesterone: a model for studying ovarian follicular dominance. Endocrinology 127, $916-925$.

Swanson, L.V., Hafs, H.D. \& Morrow, D.A. (1972) Ovarian characteristics and serum LH, prolactin, progesterone and glucocorticoid from first estrus to breeding size in Holstein heifers. J. Anim. Sci. 34, $284-293$.

Tsonis, C.G., Cahill, L.P., Carson, R.S. \& Findlay, J.K. (1984a) Identification at the onset of Iuteolysis of follicles capable of ovulation in the ewe. $J$. Reprod. Fert. 70, 609-614.

Tsonis, C.G., Carson, R.S. \& Findlay, J.K. (1984b) Relationships between aromatase activity, follicular fluid oestradiol-17 $\beta$ and testosterone concentrations, and diameter and atresia of individual ovine follicles. J. Reprod. Ferl. 72, 153-163. 
Turnbull, K.E., Braden, A.W.H. \& Mattner, P.E. (1977) The pattern of follicular growth and atresia in the ovine ovary. Aust. J. biol. Sci. 30, 229-241.

Turzillo, A.M. \& Fortune, J.E. (1990) Suppression of the secondary FSH surge with bovine follicular fluid is associated with delayed ovarian follicular development in heifers. J. Reprod. Fert. 89, 643-653.

Webb, R., Gauld, I.K. \& Driancourt, M.A. (1989) Morphological and functional characterization of large antral follicles in three breeds of sheep with different ovulation rates. J. Reprod. Fert. 87, 243-255.

Zeleznik, A.J. (1989) Follicle selection in primates. In Follicular Development and the Ovulatory Response, pp. 11-20. Eds A. Tsafriri \& N. Dekel Ares-Serono Symposia, Rome. 